\title{
PENGEMBANGAN BUKU SISWA DAN BUKU PETUNJUK GURU MATEMATIKA BERORIENTASI PEMECAHAN MASALAH DENGAN SETTING 5E
}

\author{
Margaretha N. Inna ${ }^{1)}$, Sumadi ${ }^{2)}$ \\ ${ }^{1)}$ SMK Negeri 1 Denpasar, Jl Cokroaminoto no 84, Denpasar, margaretha1804@gmail.com \\ ${ }^{2)}$ PPPPTK Matemtika, Jl.Kaliurang Km 6, Sleman, DIY, sumadi5864@gmail.com
}

\begin{abstract}
ABSTRAK. Penelitian ini bertujuan untuk mengembangkan dan menghasilkan buku siswa dan buku petunjuk guru untuk pembelajaran materi Sitem Persamaan Linear Dua Variabel berorientasi pemecahan masalah dengan setting 5E. Jenis penelitian ini adalah penelitian pengembangan dengan model pembelajaran yang berorientasi pemecahan masalah dengan setting $5 \mathrm{E}$ dengan perangkat pendukung pembelajaran yang meliputi buku siswa, buku petunjuk guru dan RPP. Pengembangan buku siswa dan buku petunjuk guru mengikuti prosedur pengembangan model Plom. Subyek yang penelitian ini adalah siswa kelas X SMK Negeri 1 Denpasar yang berjumlah 36 orang. Buku siswa yang dikembangkan valid dengan skor 3, sedangkan pada buku petunjuk guru sebesar 3,8 dengan kategori sangat valid. Pada uji keparkatisan I, buku siswa dan buku petunjuk guru yang dikembangkan mencapai skor rata-rata 3,1 dengan kategori praktis, sedangkan pada pada uji lapangan II sebesar 3,2 dengan kategori praktis. Keefektifan buku siswa dan buku petunjuk guru pada uji coba lapangan 1 mencapai skor 78,92 dengan kategori baik, sedangkan pada uji coba lapangan 2 diperoleh skor 86,07 dengan kategori amat baik. Hal ini menunjukkan buku siswa dan buku petunjuk guru berorientasi pemecahan masalah dengan setting $5 \mathrm{E}$ layak digunakan sebagai sumber belajar matematika SMK, karena memenuhi kriteria validitas, kepraktisan, dan keefektifan.
\end{abstract}

Kata Kunci: Buku Siswa, Buku Petunjuk Guru, pemecahan masalah, setting 5E

\section{DEVELOPMENT OF PROBLEM SOLVING- ORIENTED MATHEMATICS STUDENT BOOK AND TEACHER MANUAL BOOK WITH 5E SETTINGS}

\begin{abstract}
This study aims to develop and produce student book and teacher manual book in teaching and learning for the topic of Problem Solving-oriented Linear Equation System of Two Variables with $5 E$ setting. This is a development research on problem solving-oriented learning models with $5 E$ settings. The research utilises supporting learning devices that includes student books, teacher manuals and lesson plans. The process of developing student books and teacher manuals refers to the Plom model of developing procedure. Subject of this study is 36 students of grade X Vocational School 1 Denpasar. The student book which was developed is valid with a score of 3 , while the teacher's manual score is 3.8 with a quite valid category. In the first practicallity test, the average score of student books and teacher manuals was 3.1, while in the second field test the score was 3.2, it is in the practical categories.The effectiveness of student books and teacher manuals in field trial 1 reached a score of 78.92 (good), while in the field trial 2 the score was 86.07 (very good). This fact shows that the problem solving-
\end{abstract}


oriented student books and teacher manuals with the $5 E$ setting are worthy to be used as learning sources for vocational mathematics, because they meet the criteria for validity, practicality, and effectiveness

Keywords : Student Book, Teacher Manual, Problem Solving, 5E setting

\section{PENDAHULUAN}

Kemajuan suatu bangsa ditentukan oleh kualitas sumber daya manusia yang ada. Sumber daya manusia yang baik dapat memberikan sumbangan ke arah positif bagi perkembangan peradaban suatu bangsa. Upaya dan usaha perbaikan dilakukan di berbagai sektor, salah satunya adalah melalui sektor pendidikan yang merupakan sektor cukup strategis dalam mengembangkan sumber daya manusia guna menghasilkan sumber daya manusia yang bermutu tinggi (Ardana Mujiati \& Utama.al., 2012). Kualitas pendidikan yang baik dapat dilihat dari tersedianya fasilitas pendukung di setiap jenjang pendidikan, kompetensi guru yang cukup tinggi, lingkungan belajar yang kondusif, output berkualitas yang dapat bersaing di negara sendiri maupun di kancah internasional. Melalui Undang-undang Nomor 20 Tahun 2003 Tentang Sistem pendidikan Nasional, pemerintah telah mengupayakan berbagai cara untuk meningkatkan mutu pendidikan. Undang-undang ini mengamanatkan pembaharuan yang besar dalam sistem pendidikan saat ini.

Tujuan pembelajaran matematika SMK sebagaimana diuraikan dalam Lampiran III Permendikbud Nomor 60 tahun 2014 antara lain: 1) Memahami Konsep matematika, menjelaskan keterkaitan konsep serta mengaplikasikan konsep dan algoritma secara luwes, akurat, efisien, dan tepat dalam pemecahan masalah; 2) Menggunakan penalaran pada pola dan sifat, melakukan manipulasi matematika dalam membuat generalisasi, menyusun bukti atau menjelaskan gagasan atau pernyataan matematika; 3) Memecahkan masalah yang meliputi kemampuan memahami masalah, merancang model matematika, menyelesaikan model dan menafsirkan solusi yang diperoleh; 4) Mengkomunikasikan gagasan dengan symbol, tabel, diagram, atau media lain untuk memperjelas keadaan atau masalah,: dan 5) Memiliki sikap menghargai kegunaan matematika dalam kehidupan, yaitu memiliki rasa ingin tahu, perhatian, dan minat dalam mempelajari matematika, serta sikap ulet dan percaya diri dalam pemecahan masalah. Untuk mencapai tujuan tersebut berbagai upaya peningkatan mutu pendidikan telah dilakukan oleh pemerintah, diantaranya adalah peyempurnaan kurikulum, pengadaan buku ajar, penyediaan sarana dan prasarana, peningkatan mutu guru dan tenaga kependidikan melalui pelatihan dan peningkatan kualitas pendidikan.

Meskipun berbagai upaya yang telah dilakukan pemerintah namun hasilnya belum seperti yang diharapkan. Hasil penilaian PISA di bidang matematika pada tahun 2015 yang menambahkan penilaian literasi pemecahan masalah, menunjukkan siswa di Indonesia menempati peringkat ke 69 dari 76 negara yang berpartisipasi. Prestasi siswa Indonesia pada PISA yang hampir berada di posisi terakhir dari beberapa negara yang ikut berpartisipasi, disinyalir disebabkan oleh beberapa hal berikut ini: 1) Lemahnya kemampuan pemecahan masalah dan soal-soal kontekstual yang diambil dari dunia nyata, 2) Sistem evaluasi di Indonesia masih menggunakan soal level rendah, 3) Lemahnya kemampuan pemecahan masalah juga dipengaruhi oleh sistem evaluasi Indonesia, dan 4) Siswa tidak terbiasa dengan pembelajaran yang diawali dengan permasalahan sehari-hari (Kertayasa, 2015). Lemahnya 
kemampuan pemecahan masalah pada siswa dipengaruh dari proses pembelajaran yang terjadi dikelas. Ruseffendi dalam Juniantari (2011) menyatakan bahwa matematika penting sebagai pembimbing pola pikir maupun sebagai pembentuk sikap. Disamping itu matematika juga menyumbang keterampilan kepada seseorang dalam hal daya abstraksi, analisis permasalahan dan penalaran logika. Polya (1957) mengatakan pemecahan masalah adalah salah satu aspek berpikir tingkat tinggi, sebagai proses menerima masalah dan berusaha menyelesaikan masalah tersebut.Suatu masalah biasanya memuat situasi yang mendorong siswa untuk menyelesaikannya, akan tetapi tidak tahu secara langsung apa yang harus dikerjakan untuk menyelesaikannya. Jika suatu masalah diberikan kepada seorang siswa dan siswa tersebut langsung mengetahui cara menyelesaikan dengan benar maka soal tersebut tidak dapat dikatakan suatu masalah. Pada saat siswa menemukan masalah maka telah terjadi perbedaan keseimbangan dengan keadaan awal. Siswa perlu mengonstruksi suatu keseimbangan baru artinya ketika siswa mengalami konflik kognitif, ia akan berusaha untuk mencapai keseimbangan baru, yaitu solusi atas masalah yang dihadapi. Apabila siswa mampu menemukan konflik dan mampu menyelesaikannya maka sebenarnya tahap kognitifnya telah meningkat.

Snyder dan Snyder (2008) menyatakan bahwa untuk mengembangkan kemampuan siswa melalui pembelajaran dapat dilakukan dengan: 1) menggunakan strategi pembelajaran yang melibatkan siswa secara aktif dalam proses belajar, 2) memfokuskan pembelajaran pada proses belajar dari pada hanya mengandalkan konten, dan 3) menggunakan instrumen penilaian yang memberikan siswa tantangan intelektual dan bukan kemampuan mengahafal prosedur atau konsep tertentu. Dengan kata lain guru perlu merancang pembelajaran yang melibatkan siswa secara aktif dalam pembelajaran matematika, misalnya dengan melaksanakan pembelajaran yang berorientasi pemecahan masalah, dalam artian siswa belajar memahami konsep matematika melalui penyelesaian masalah.

Pembelajaran yang berorientasi pemecahan masalah merupakan pembelajaran yang menekankan pada penyelesaian masalah dengan tujuan melalui penyelesaian masalah siswa mampu menemukan dan memahami konsep matematika yang dipelajari. Kemampuan belajar siswa dapat dikembangkan melalui pengalaman-pengalaman yang diperoleh siswa pada proses pemecahan masalah matematika. Pada pembelajaranyang berorientasi pemecahan masalah, guru memberikan permasalahan sehari-hari yang akan didiskusikan oleh siswa untuk untuk menemukan penyelesaiannya. Dengan menemukan penyelesaian masalah tersebut diharapkan siswa mampu mengaitkan solusi dari masalah dengan konsep matematika.

Pembelajaran pemecahan masalah memerlukan tahapan-tahapan yang dapat memfasilitasi siswa untuk memunculkan pemahaman siswa. Dengan demikian dalam pelaksanaan pembelajaran pemecahan masalah diperlukan model pembelajaran yang memberikan kesempatan kepada siswa aktif bereksplorasi, mengolah ide-ide mereka, menguji hipotesis dan mengemukakan pendapat mereka dalam memecahkan masalah matematika. Salah satu model pembelajaran yang dapat dilaksanakan untuk menunjang pelaksanaan pembelajaran berorientasi pemecahan masalah adalah 5E, yaitu engagement, eksplanation, eksploration, elaboration, evaluation. Lorsbach (Agustyaningrum, 2010) menguraikan setiap tahapan sebagai berikut: 
a. Tahap Engagement.

Pada tahap ini guru menyiapkan atau mengondisikan siswa untuk belajar, membangkitkan minat siswa pada pelajaran matematika, dan melakukan tanya jawab dalam mengeksplorasi pengetahuan awal siswa.

b. Tahap Exploration.

Pada tahap ini siswa bekerja sama dalam kelompok kelompok kecil untuk mengerjakan LKS tanpa pengajaran langsung dari guru. Siswa mempelajari konsep sendiri dari berbagai sumber yang dimiliki dan mendiskusikan dengan teman kelompoknya. Dalam hal ini guru berperan sebagai fasilitator.

c. Tahap Explanation.

Tahap ini merupakan tahap diskusi klasikal. Pada tahap ini siswa menjelaskan konsep hasil temuan kelompoknya dengan kata-kata mereka sendiri, menunjukkan bukti dan klarifikasi dari penjelasan mereka, serta membandingkan argumen yang mereka miliki dengan argumen dari siswa lain.

d. Tahap Elaboration.

Pada tahap ini siswa mengaplikasikan konsep yang mereka dapatkan untuk menyelesaikan soal-soal pemecahan masalah.

e. Tahap Evaluation.

Evaluasi dapat dilakukan melalui pemberian tes (quiz) atau open-ended question di akhir pembelajaran untuk mengetahui sejauh mana tingkat pemahaman siswa terhadap konsep yang dipelajari.

Untuk dapat melaksanakan pembelajaran model 5E, diperlukan buku siswa dan buku petunjuk guru yang baik. Model 5E dapat membantu siswa dalam mencapai pemahaman yang lebih baik terhadap konsep matematika serta aplikasinya dengan cara mengaitkan pengetahuan yang dimiliki dengan materi pembelajaran yang disampaikan sehingga pembelajaran menjadi link and macth dengan kehidupan nyata siswa. Pembelajaran yang dapat mengaitkan meteri dengan kehidupan nyata siswa,menjadikan pembelajaran tersebut bermakna dan dapat membantu siswa dalam pencapaian pemahaman yang lebih baik terhadap konsep matematika. Hal ini sesuai dengan teori belajar bermakna yang dikemukakan Ausubel (Dahar, 1998) yang menyatakan bahwa akan bermakna apabila siswa dapat mengaplikasikan pelajarannya dalam kehidupan nyata. Selain itu, agar terjadi belajar bermakna, konsep baru atau pengetahuan baru harus dikaitkan dengan konsep yang telah ada dalam struktur kognitif pebelajar, pengembangan sikap, dan keterampilan secara menyeluruh.

Pelaksanaan Model 5E dapat mengembangkan kinerja ilmiah siswa yaitu pada tahap eksploration, dan Elaboration. Melalui fase eksploration dan elaboration siswa memperoleh kesempatan untuk terlibat aktif dalam pembelajaran dengan mengalami sendiri apa yang mereka pelajari melalui demonstrasi maupun eksperimen. Hal ini akan dapat meningkatkan keterampilan siswa dalam melakukan percobaan. Siswa juga diberikan kesempatan melakukan unjuk kerja sehingga siswa aktif berinteraksi dalam proses pembelajaran serta mengajak siswa mengaplikasikan konsep-konsep yang mereka dapatkan dengan mengerjakan soal-soal pemecahan masalah dan terdapat suatu tes akhir untuk mengetahui sejauh mana tingkat pemahaman siswa terhadap konsep yang telah dipelajari.

Berdasarkan uraian diatas perlu dilakukan pengembangan buku siswa dan buku petunjuk guru matematika dengan judul "Pengembangan Buku Siswa dan Buku Guru Matematika 
Berorientasi Pemecahan Masalah dengan Setting 5E”. Penelitian ini bertujuan untukmengembangkan dan menghasilkan buku siswa dan buku petunjuk guru matematika berorientasi pemecahan masalah dengan setting $5 \mathrm{E}$.

\section{METODE}

Penelitian ini adalah penelitian jenis pengembangan (Research and Development). Pengembangan buku siswa buku petunjuk guru dalam penelitian ini mengikuti prosedur pengembangan pembelajaran. Menurut Plom (2010), pelaksanaan penelitian pengembangan meliputi 3 fase yaitu : 1) Fase Preliminary research (Penelitian Awal), 2) Fase Prototyping (proses iterasi analisis, disain dan pengembangan, evaluasi formatif dan revisi), 3) Fase Assesment (penilaian semi sumatif). Aspek yang dinilai dalam penelitian ini adalah aspek validitas, aspek kepraktisan, dan aspek keefektifan. Instrumen yang digunakan dalam penelitian ini yaitu: (1) lembar validitas buku siswa dan buku petunjuk guru untuk mengukur validitas konstruks dari pakar; (2) lembar pengamatan keterlaksanaan buku siswa buku petunjuk guru; (3) angket respon siswa terhadap pembelajaran untuk mengukur kepraktisan buku siswa buku petunjuk guru; (4) angket respon guru terhadap pembelajaran untuk mengukur kepraktisan buku siswa buku petunjuk guru dan (5) tes hasil belajar untuk mengukur efektivitas buku siswa buku petunjuk guru yang dikembangkan. Data yang telah dikumpulkan diolah secara deskriptif. Kualitas buku siswa dan buku petunjuk guru yang dikembangkan dalam penelitian ini dinilai dari segi validitas, kepraktisan, dan efektivitasnya. Oleh karena itu, dalam rangka menentukan kualitas buku yang dikembangkan diperlukan tiga macam data yaitu: validitas, kepraktisan, dan efektivitas buku siswa dan buku petunjuk guru yang dikembangkan. Untuk memperoleh data penelitian, dilakukan melaui angket, observasi, dan tes. Untuk lebih detail dapat dijelaskan sebagai berikut.

\subsection{Hasil Validasi Buku Siswa dan Buku Petunjuk Guru}

Validitas buku siswa dan buku petunjuk guru diukur berdasarkan validitas isi dan validitas konstruksnya. Validitas isi dilihat dari proses pengembangan dari kesesuaian buku siswa buku petunjuk guru yang dikembangkan dengan teori yang mendukung, yang dinilai oleh expert judgment. Validitas konstruks pada penelitian ini dilihat berdasarkan keterkaitan dan kesesuaian komponen yang ada dalam buku siswa dan buku petunjuk guru dengan teori pembelajaran yang dipakai sebagai landasan. Validitas konstruks dari buku siswa dan buku petunjuk guru ini ditentukan berdasarkan pendapat pakar dari Universitas Ganesha Singaraja. Untuk menguji validitas konstruks, masing-masing pakar diberikan lembar validitas, dimana pada lembar validitas tersebut memuat beberapa aspek yang meliputi: karkateristik buku siswa buku petunjuk guru dan isi buku siswa dan buku petunjuk guru. Dalam lembar validasi pendapat validator dikategorikan menjadi empat skala penilaian, yaitu: sangat baik (skor 4), baik (skor 3), kurang (skor 2), sangat kurang (skor 1). Masing-masing pakar kemudian menilai seberapa besar kesesuaian antara buku siswa buku petunjuk guru dan aspek-aspek yang terdapat pada lembar validasi, dengan mencentang salah satu skala penilaian yang tertera pada kolom lembar validasi. Validitas buku siswa buku petunjuk guru ditentukan dengan mengkonversi rata-rata skor total menjadi nilai kualitatif dengan menggunakan kriteria berikut. 
Tabel 1. Kriteria Kevalidan Buku Siswa Buku Petunjuk Guru

\begin{tabular}{|l|l|}
\hline \multicolumn{1}{|c|}{ Skor } & \multicolumn{1}{c|}{ Kriteria } \\
\hline $3,5 \leq \mathrm{Sr} \leq 4,0$ & Sangat valid \\
\hline $2,5 \leq \mathrm{Sr}<3,5$ & Valid \\
\hline $1,5 \leq \mathrm{Sr}<2,5$ & Tidak valid \\
\hline $1,0 \leq \mathrm{Sr}<1,5$ & Sangat tidak valid \\
\hline
\end{tabular}

\subsection{Kepraktisan Buku Siswa Buku Petunjuk Guru}

Kepraktisan buku siswa dan buku petunjuk guru diukur berdasarkan keterlaksanaannya di kelas. Data mengenai kepraktisan buku siswa dan buku petunjuk guru yang dikembangkan diperoleh dari hasil pengamatan keterlaksanaan buku siswa dan buku petunjuk guru, angket respons guru terhadap buku siswa buku petunjuk guru, dan angket respons siswa terhadap buku siswa buku petunjuk guru setelah mengikuti pembelajaran.

Pengamatan keterlaksanaan buku siswa dan buku petunjuk guru dilakukan dengan mengamati tiap-tiap aspek yang terdapat pada lembar pengamatan pada tiap pertemuan. Dalam lembar pengamatan, lembar respon siswa, dan lembar respon guru, penilaiannya dikatagorikan, menjadi empat skala penilaian, yaitu: sangat baik (skor 4), baik (skor 3), kurang ( skor 2), sangat kurang (skor 1). Data yang diproleh kemudian dianalisis dan untuk melihat nilai kepraktisan buku siswa buku petunjuk guru yang dikembangkan, nilai rata-rata skor yang diperoleh dikonversikan berdasarkan kriteria sebagai berikut.

Tabel 2. Kriteria Kepraktisan Buku Siswa Buku Petunjuk Guru

\begin{tabular}{|l|l|}
\hline \multicolumn{1}{|c|}{ Skor } & \multicolumn{1}{c|}{ Kriteria } \\
\hline $3,5 \leq \mathrm{Sr} \leq 4,0$ & Sangat praktis \\
\hline $2,5 \leq \mathrm{Sr}<3,5$ & Praktis \\
\hline $1,5 \leq \mathrm{Sr}<2,5$ & Tidak praktis \\
\hline $1,0 \leq \mathrm{Sr}<1,5$ & Sangat tidak praktis \\
\hline
\end{tabular}

\subsection{Efektivitas Buku Siswa Buku Petunjuk Guru}

Efektivitas buku siswa dan buku petunjuk guru diukur berdasarkan ketercapaian tujuan pembelajaran yang menggunakan buku siswa dan buku petunjuk guru yang dikembangkan. Untuk menilai keefektipan buku siswa buku petunjuk guru dilakukan dengan mengumpulkan data melalui tes kemampuan komunikasi matematika berbentuk soal uraian. Pemberian Skor pada masing-masing soal dilihat dari indikator tes hasil belajar matematika. Untuk melihat nilai keefektifan buku siswa dan buku petunjuk guru yang dikembangkan berdasarkan data tes hasil belajar matematika, maka data tersebut dikonversikan berdasarkan kriteria sebagai berikut. 
Tabel 3 Konversi Skor Tes Hasil Belajar Matematika

\begin{tabular}{|c|c|}
\hline Skor & Kriteria \\
\hline skor $<75,00$ & Kurang \\
\hline $75,00 \leq$ skor $\leq 86,00$ & Baik \\
\hline skor $\geq 86,00$ & Sangat Baik \\
\hline
\end{tabular}

\section{HASIL DAN PEMBAHASAN}

\subsection{Produk Hasil Pengembangan}

Produk yang dihasilkan pada penelitian pengembangan ini adalah Buku Siswa dan Buku Petunjuk Guru untuk pembelajaran matematika SMK Kelas X Materi Sistem Persamaan Linear Dua Variabel. Materi ini membelajarkan kompetensi dasar: 1) Menentukan nilai variabel pada sistem persamaan linear dua variabel dalam masalah kontekstual, dan 2) Menyelesaikan masalah sistem persamaan linier dua variabel.

Buku siswa dan buku petunjuk guru ini merupakan buku siswa dan buku petunjuk guru edisi pertama yang dihasilkan melalui proses validasi konten oleh expert judgement dan dua kali ujicoba lapangan. Dalam proses pengembangan buku siswa dan buku petunjuk guru ini, dilakukan dua kali revisi berdasarkan hasil ujicoba lapangan I dan ujicoba lapangan II.

\subsection{Hasil validasi ahli Buku Siswa dan Buku Petunjuk Guru}

Validator yang melakukan validasi terhadap buku siswa dan buku petunjuk guru yang dikembangkan terdiri dari dua orang ahli yaitu yang merupakan pakar dari Universitas Pendidikan Genesha Singaraja. Adapun skor rata-rata hasil validasi disajikan pada tabel berikut ini.

Tabel 4. Rekapitulasi Validitas Buku Siswa dan Buku Petunjuk Guru

\begin{tabular}{|l|l|c|c|}
\hline No. & \multicolumn{1}{|c|}{ Perangkat Pembelajaran } & Rata-Rata & Kriteria \\
\hline 1. & Buku Siswa & 3,7 & Sangat Valid \\
\hline 2. & Buku Petunjuk Guru & 3,8 & Sangat Valid \\
\hline
\end{tabular}

Berdasarkan tabel di atas, dapat diketahui bahwa buku siswa dan buku petunjuk guru yang dikembangkan sudah memenuhi aspek valid. Hal ini ditunjukkan pada nilai rata-rata Buku Siswa 3,7 yang menunjukkan bahwa buku siswa memiliki kriteria sangat valid. Buku Petunjuk Guru mendapatkan nilai rata-rata 3,8 yang menyatakan bahwa buku siswa dan buku petunjuk guru tersebut juga memenuhi kriteria sangat valid.

\subsection{Kepraktisan Buku Siswa dan Buku Petunjuk Guru}

Kepraktisan buku siswa dan buku petunjuk guru dalam penelitian ini dinilai berdasarkan pada keterlaksanaan pembelajaran menggunakan buku siswa dan buku petunjuk guru yang dikembangkan selama kegiatan pembelajaran matematika 
berlangsung di kelas. Pengamatan keterlaksanaan buku siswa dan buku petunjuk guru diamati oleh dua orang pengamat. Rekapitulasi mengenai hasil pengamatan keterlaksanaan buku siswa dan buku petunjuk guru dalam pembelajaran disajikan pada tabel berikut.

Tabel 5. Rekapitulasi Data Hasil Pengamatan Keterlaksanaan buku siswa buku guru

\begin{tabular}{|c|c|c|c|c|c|}
\hline No & Pengamatan & $\begin{array}{c}\text { Skor Rata-Rata } \\
\text { Pengamat 1 }\end{array}$ & $\begin{array}{c}\text { Skor Rata-Rata } \\
\text { Pengamat 2 }\end{array}$ & $\begin{array}{c}\text { Skor Rata- } \\
\text { Rata Total }\end{array}$ & Kriteria \\
\hline 1. & Uji Coba Terbatas & 2,9 & 3,0 & 2,9 & Praktis \\
\hline 2. & Uji Coba Lapangan 1 & 3,1 & 3,1 & 3,1 & Praktis \\
\hline 3. & Uji Coba Lapangan 2 & 3,2 & 3,2 & 3,2 & Praktis \\
\hline
\end{tabular}

Berdasarkan tabel di atas dapat dianalisis bahwa terjadi peningkatan nilai rata-rata skor mulai dari uji coba terbatas hingga uji coba lapangan 2. Dalam penelitian ini, uji coba hanya dilakukan sampai uji coba lapangan 2. Terlihat bahwa skor rata-rata pengamatan keterlaksanaan pembelajaran pada uji coba lapangan 2 adalah 3,2. Berdasarkan kriteria yang telah ditetapkan, maka buku siswa buku petunjuk guru yang dikembangkan termasuk dalam kriteria praktis, karena Sr berada pada rentang $2,5 \leq \mathrm{Sr}<3,5$. Data mengenai respons siswa diisi oleh 8 orang siswa pada uji coba terbatas, 28 siswa pada uji coba lapangan 1, dan 28 orang siswa pada uji coba lapangan 2.

Adapun rekapitulasi mengenai respons siswa terhadap buku siswa buku petunjuk guru disajikan pada tabel 6 .

Tabel 6. Rekapitulasi Data Respons Siswa Terhadap Buku Siswa

\begin{tabular}{|c|l|c|l|}
\hline No. & \multicolumn{1}{|c|}{ Respons Siswa } & Skor Rata-Rata & \multicolumn{1}{|c|}{ Kriteria } \\
\hline 1. & Uji Coba Terbatas & 2,9 & Praktis \\
\hline 2. & Uji Coba Lapangan 1 & 3,2 & Praktis \\
\hline 3. & Uji Coba Lapangan 2 & 3,3 & Praktis \\
\hline
\end{tabular}

Berdasarkan tabel di atas dapat dianalisis bahwa terjadi peningkatan nilai rata-rata skor mulai dari uji coba terbatas hingga uji coba lapangan 2. Dalam penelitian ini, uji coba hanya dilakukan sampai uji coba lapangan 2. Terlihat bahwa skor rata-rata respons siswa terhadap buku siswa buku petunjuk guru pada uji coba lapangan 2 adalah 3,3. Berdasarkan kriteria yang telah ditetapkan, maka buku siswa buku petunjuk guru yang dikembangkan termasuk dalam kategori praktis, karena $\mathrm{Sr}$ berada pada rentang $2,5 \leq \mathrm{Sr}<3,5$. Data mengenai respons guru terhadap buku siswa buku petunjuk guru diisi oleh guru yang melaksanakan pembalajaran saat uji coba terbatas, uji coba lapangan 1, dan uji coba lapangan 2. Adapun rekapitulasi mengenai respons guru terhadap buku siswa buku petunjuk guru disajikan pada tabel berikut. 
Tabel 7. Rekapitulasi Data Respons Guru terhadap Buku siswa Buku Guru

\begin{tabular}{|c|l|c|l|}
\hline No. & \multicolumn{1}{|c|}{ Respons Guru } & Skor Rata-Rata & \multicolumn{1}{|c|}{ Kriteria } \\
\hline 1. & Uji Coba Terbatas & 2,8 & Praktis \\
\hline 2. & Uji Coba Lapangan 1 & 3,4 & Praktis \\
\hline 3. & Uji Coba Lapangan 2 & 3,6 & Sangat Praktis \\
\hline
\end{tabular}

Berdasarkan tabel di atas dapat dianalisis bahwa terjadi peningkatan nilai rata-rata skor mulai dari uji coba terbatas hingga uji coba lapangan 2. Dalam penelitian ini, uji coba hanya dilakukan sampai uji coba lapangan 2. Terlihat bahwa skor rata-rata respons guru terhadap buku siswa buku petunjuk guru pada uji coba lapangan 2 adalah 3,6. Berdasarkan kriteria yang telah ditetapkan, maka buku siswa buku petunjuk guru yang dikembangkan termasuk dalam kategori sangat praktis, karena Sr berada pada rentang 3,5 $\leq \mathrm{Sr}<4,0$.

\subsection{Efektivitas Buku siswa dan Buku Petunjuk Guru}

Efektivitas produk dilihat dari ketercapaian tujuan pembelajaran dengan penerapan dan penggunaan produk. Untuk menilai efektivitas buku siswa dan buku petunjuk guru, digunakan tes hasil belajar matematika. Sesuai dengan model Plomp, penilaian hasil belajar matematika siswa dilakukan dengan pemberian tes semi sumatif setelah draft IV diujicoba dalam uji coba lapangan 1 dan uji coba lapangan 2 untuk melihat peningkatan efektivitas produk yang terdiri dari 8 soal uraian. Tes ini sebelumnya telah diuji cobakan pada kelas yang heterogen dengan kelas yang digunakan dalam penelitian. Dari hasil analisis tes hasil belajar matematika telah mencapai valid dan reliabel. Adapun rekapitulasi mengenai tes hasil belajar matematika siswa disajikan pada tabel 8 .

\section{Tabel 8. Rekapitulasi Hasil Tes Hasil Belajar Matematika Siswa}

\begin{tabular}{|c|c|c|}
\hline Hasil Tes & Rata-rata Skor Total & Kriteria \\
\hline Uji Coba Lapangan 1 & 78,92 & Baik \\
\hline Uji Coba Lapangan 2 & 86,07 & Sangat Baik \\
\hline
\end{tabular}

Berdasar rata-rata skor tes pada uji coba lapangan 1 sebesar 78,92 maka dapat dikatakan bahwa efektivitas produk tergolong kategori " baik", karena nilai ini terletak pada interval $\bar{X}>75$. Hasil uji coba lapangan 2 diperoleh rata-rata skor tes adalah 86,07, maka efektivitas produk dapat dikatakan tergolong kategorisangat "baik", karena nilai ini terletak pada interval $\bar{X}>75$. Dari uraian tersebut diperoleh buku siswa dan buku petunjuk guru matematika berorientasi pemecahan masalah valid, praktis, dan efektif.

Buku siswa diawali dengan permasalahan kehidupan sehari-hari siswa. Permasalahan tersebut merupakan permasalahan untuk menggali pengetahuan awal siswa dan melalui pengetahuan awal yang dimiliki siswa akan mempermudah dalam menyelesaikan permasalahan yang akan didiskusikan siswa. Aktivitas belajar pada buku siswa berupa kegiatan diskusi kelompok untuk menyelesaikan permasalahan yang disediakan. Melalui kegiatan ini akan melatih siswa untuk berpikir dan mengeluarkan ide-ide secara alami dalam 
membuat konsep jawaban serta merumuskan argumen-argumen yang masuk akal, memberikan penilaian terhadap masalah serta dapat memberikan alternatif penyelesaian terhadap permasalahan. Soal latihan pada buku siswa lebih menekankan pada permasalahan kehidupan sehari-hari. Melalui permasalahan ini diharapkan melatih kemampuan berpikir siswa dalam menyelesaikan masalah matematika dan meningkatkan pemahaman siswa mengenai materi yang dipelajari dan tiap soal latihan memiliki tingkat kesulitan yang berbeda dengan tujuan untuk meningkatkan pemahaman siswa dan hasil tes belajar. Aktivitas belajar siswa dibuat berdasarkan proses pembelajaran berorientasi pemecahan masalah dengan setting $5 \mathrm{E}$

Buku petunjuk guru disusun untuk mempermudah guru dalam membelajarkan siswa yang berisikan petunjuk dan langkah yang dapat dilaksanakan guru. Buku petunjuk guru terdiri dari petunjuk penggunaan buku, deskripsi singkat pembelajaran berorientasi pemecahan masalah dengan setting 5E, kompetensi dasar, tujuan pembelajaran dan petunjuk pelaksanaan pembelajaran berorientasi pemecahan masalah dengan setting 5E. Petunjuk penggunaan dibuat agar guru dapat menggunakan buku petunjuk guru dengan baik, sehingga tidak ada kekeliruan dalam penerapan buku pada pembelajaran dikelas. Deskripsi singkat pembelajaran berorientasi pemecahan masalah dengan setting $5 \mathrm{E}$ diberikan agar guru memahami dan mampu menerapkan model pembelajaran berorientasi masalah dengan setting 5E dengan baik.

Tahap pembelajaran pada buku petunjuk guru sesuai dengan pembelajaran berorientasi pemecahan masalah dengan setting 5E. Petunjuk pelaksanaan pembelajaran pada buku petunjuk guru lebih menempatkan guru sebagai fasilitator dalam pembelajaran berkelompok. Petunjuk pelaksanaan pembelajaran mempermudah guru memfasilitasi siswa dalam kelompok belajar. Guru memberikan bimbingan dan petunjuk pada saat siswa mengalami kesulitan dalam berdiskusi kelompok. Buku petunjuk guru memuat substansi buku siswa dan alternatif penyelesaian permasalahan untuk mempermudah guru dalam melaksanakan pembelajaran dan guru mudah melihat aktivitas belajar pada buku siswa dan halamannya melalui buku petunjuk guru tanpa perlu melihat buku siswa. Alternatif penyelesaian permasalahan dapat digunakan guru sebagai pedoman dalam membimbing siswa saat berdiskusi kelompok. Buku petunjuk guru menyediakan soal evaluasi yang dapat digunakan guru diakhir pembelajaran untuk mengetahui pemahaman siswa setelah belajar.

Karakteristik Pembelajaran Berorientasi Pemecahan Masalah dengan Setting 5E adalah: 1) pembelajaran diawali dengan pengetahuan awal untuk menumbuhkan minat belajar siswa melalui materi yang dipelajari dengan permasalahan sehari hari yang terkait dengan kehidupan siswa melalui pengetahuan yang dimiliki siswa dan akan mempermudah siswa dalam menyelesaikan masalah yang akan diberikan, 2) untuk memotivasi siswa belajar dilakukan melalui contoh penerapan materi yang akan dipelajari siswa dan memberikan pertanyaan yang terkait dengan penerapan tersebut, 3) penemuan konsep yang dilakukan melalui penyelesaian permasalahan kehidupan sehari-hari siswa, penyelesaian permasalahan tersebut dilakukan melalui diskusi kelompok dengan guru sebagai fasilitator dalam pembelajaran, dan 4) Pemahaman siswa ditingkatkan melalui latihan soal-soal pengembangan dimana soal tersebut lebih menekankan pada permasalahan sehari-hari yang dekat dengan kehidupan siswa. 


\section{SIMPULAN}

Berdasarkan hasil penelitian dan pembahasan di atas dapat disimpulkan bahwa buku siswa dan buku guru yang dikembangkan sangat valid dengan nilai skor rata-rata validasi pada buku siswa sebesar 3,7 dengan kategori sangat valid, sedangkan pada buku petunjuk guru sebesar 3,8 dengan kategori sangat valid. Kepraktisan buku siswa dan buku petunjuk guru yang dikembangkan mencapai skor rata-rata 3,1 pada uji coba lapangan I sebesar dengan kategori praktis, sedangkan pada pada uji lapangan II sebesar 3,2 dengan kategori praktis

\section{DAFTAR PUSTAKA}

Agustyaningrum, N. (2010). Implementasi Model Pembelajaran Leyle 5E untuk Meningkatkan Komunikasi Matematis Siswa Kelas IX B SMP Negeri 2 Sleman. Skripsi, Yogyakarta: Universitas Negeri Yogyakarta, 2010. Diakses tanggal 11 Agustus 2018.

Ardana, I.K., Mujiati, N.W, dan Utama, I.W.M. (2012). Manajemen sumber daya manusia. Yogyakarta: Graha Ilmu

Dahar, R.W.(1988). Teori-Teori Belajar. Jakarta: Erlangga

Juniantari, M. 2011. Pengembangan Perangkat Pembelajaran Matematika Realistik dengan Seting Model Kooperatif MURDER bagis Siswa SMP kelas VII. Tesis (tidak diterbitkan). Singaraja: Pascasarjana Undiksha.

Kertayasa, I.K. (2015). Pengembangan Soal Model Pisa Berbasis Online. Diunduh dari www.indonesiapisacenter.com pada tanggal 10 Agustus 2018.

Plomp. (2010). "Educational Design Research: An Indroduction", dalam An Introductional to Educational Research. Enschede, Netherland: National Institute for Curriculum Development

Polya, G. (1957). How To Solve: A New Aspect of Mathematical Method. New Jersey: Princeton University Press.

Snyder, L. G., \& Snyder, M. J. (2008). Teaching critical thinking and problem solving skills. The Journal of Research in Business Education, 50(2), 90.

\section{How to Cite:}

Inna, Margaretha N., Sumadi (2019). Pengembangan buku siswa dan buku petunjuk guru matematika berorientasi pemecahan masalah dengan setting 5E. Idealmathedu: Indonesian Digital Journal of Mathematics and Education, VI(1), 558-568. 